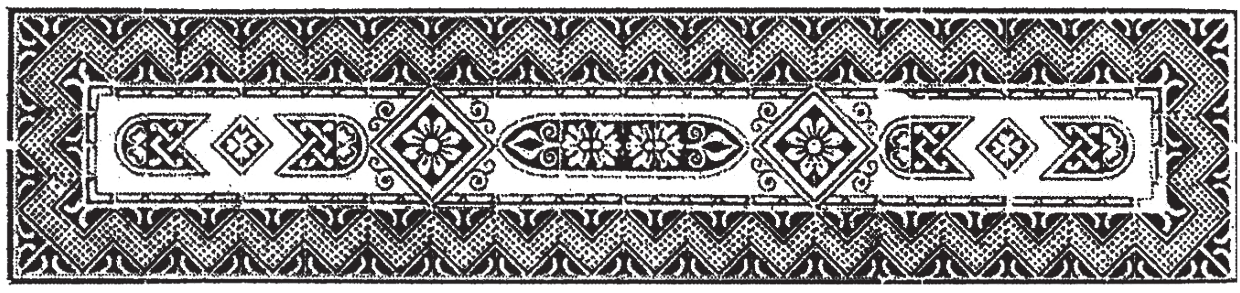

doi https://doi.org/10.18485/bratstvo.2020.24.9 УДК 398.3(=163.41)(497)"1888"

Рад примљен: 03.08.2020.

Рад прихваћен: 11.09.2020.

Оригиналан научни рад

\title{
ПРВА ПРОСЛАВА ДАНА СВЕТОГ САВЕ У МРКОЊИК ГРАДУ 1888. ГОДИНЕ
}

Радом Прва прослава Дана Светог Саве у Мркоњић Граду 1888. године скренута је пажња на Светосавску прославу и уопште прву забаву одржану у Мркоњић Граду. Наведено је ко су били учесници приредбе, садржај изведеног програма, остварени приход, као и имена добровољних прилагача на прослави. Поред тога, указано је и на какав је одзив она наишла код публике, ита је био юен значај и какве је последице имала. Редовна приређивања Светосавске прославе довела су до тога да је, после нешто више од једне деценије, основано певачко друштво под именом Српско православно ирквено пјевачко друштво „Николајевић“.

Национално свестан, српски народ у Босни и Херцеговини, под окупацијом Аустроугарске, водио је борбу за очување свог националног идентитета средствима којима је располагао и имао у датим приликама. Међу њима било је и неговање националних празника којима је подизан, а уједно и брањен национални идентитет. На један од њих овде подсећамо.

Стојан Тркуљић, млад учитељ, по завршетку богословије своју просветну, духовну и националну делатност започео је у српској основној школи у Мркоњић Граду, тада Варцар Вакуфу, 5. септембра 1887. и ту је био до 1. јула 1895. године. ${ }^{1}$ Одмах, на почетку своје учитељске службе имао је

\footnotetext{
Рођен је у селу Попуже 18 . октобра 1865 . Основну школу завршио је у Герзову, а богословију у Рељеву. После учитељске службе био је свештеник у новооснованој парохији у Језеру до јула 1908. Од тада је на Мркоњићградској парохији све до пензионисања обављао дужност пароха и архијерејског намесника. Због свог националног осећања
} 
идеју да се обележи и прослави Дан Светог Саве. Зато је предложио проти Јовану Пећанцу ${ }^{2}$ и црквеном одбору да приреде беседу и одрже забаву на

и рада од окупаторске аустроугарске власти окарактерисан је као радикалан Србин (Radikaler Serbe) и ухапшен 17/30. јула 1914. Као таоц одведен је у затвор у Јајце. Одатле је 29. децембра исте године као велеиздајник спроведен у окружни затвор у Травнику и из њега 30. јануара 1915. у окружни затвор у Сарајево у којем је под истрагом био до 26. маја, када је враћен кући и био у кућном затвору до септембра те године. Иако је као велеиздајник био у наведеним затворима, није суђен као велеиздајник. За ђакона и презвитера рукоположен је 1893, а за протојереја произведен је 1919. године. Био је, поред осталог, члан Главног одбора Свештеничког удружења Дабробосанске епархије, почасни члан Епархијског црквеног суда у Сарајеву, члан ужег Управног и просвјетног савјета Дабробосанске епархије. Писао је радове историјског, просветног и аутобиографског садржаја. Био је сарадник „Босанске виле“, „Српског свештеника“, „Новог источника“, „Отаџбине“ и од 1925. активиста у сакупљању претплатника за часопис „Братство“, покренут у Сарајеву. Почетком 1928. постављен је за сталног учитеља веронауке у основаној грађанској школи у Мркоњић Граду. Одликован је ношењем црвеног појаса, напрсним крстом, орденом Светог Саве IV степена и Златном медаљом за грађанске заслуге. Усташе су га 1941. одвеле у логор у Цапрагу и одатле протерале у Србију, где је живео и умро у Београду 5. априла 1942.

2 Јован Пећанц рођен је у селу Рашиновац код Босанског Петровца 5. јануара 1837. од оца Ђуре и мајке Јеке, рођене Драгић. Без оца остао је када је имао три године. У школу је кренуо с пуних 13 година у Босански Петровац, а учитељ му је био Обрад Павковић из Срба. Школовање је прекинуо априла 1853, због смрти мајке и стрица Аћима, и бавио се тежачким послом до 1862. Митрополит Игњатије га је рукоположио за свештеника 30. јануара 1862. у старој сарајевској цркви и дао му парохију Бјелај код Босанског Петровца. На тој парохији био је до устанка 1875. Тада се придружио устаницима и активно суделовао у устанку као стотинар (предводио 100 људи) у чети Вида Милановића. Одважан и неустрашив борац у борбама против Турака био је на: Бјелају, Босанском Петровцу, Рустову код Санског Моста, Јелашиновцу, Осјеченици, Челебићу код Лијевна, Кључу и Црним Потоцима. У борби на Јелашиновцу Турци су ухватили његовог коња којег је дао једном устанику. На коњу су биле свештеничке књиге и одежде, па су Турци, да би уплашили Србе, Јованов епитрахиљ обесили у Старом Мајдану и висио је неколико недеља. Одликован је српском медаљом за храброст. По завршетку устанка народ се вратио из збегова, па је умирао од глади, зиме и других невоља. Поп Јован је тада отишао у Книн до мис Аделине Паулине Ирби да је моли за помоћ голом и гладном народу. Та је помоћ Енглескиње многе људе спасила од умирања. На позив Срба дошао је за пароха у Мркоњић Град 28. октобра 1879. Ту је другим средствима наставио борбу за свој српски народ и Српску православну цркву. Оптужен је био да се буни против Општинског уреда када је стао у одбрану Срба, затворених због денунцијација. Због тога вођена је истрага, па је тужба одбачена. Мркоњић је 1883. задесио велики пожар и уништио је скоро цео град. Нарочито чаршију у којој су биле, већином, српске куће и радње (дућани). Изгореле су и српска школа, кућа где је поп Јован становао, као и мала црква, проста дрвена кућица претворена у црквицу. Тада је поп Јован послат од Српске црквене општине да купи милостињу (прилоге) за градњу цркве у Мркоњићу. Обишао је Босну и Херцеговину и 1885. поставио је темељ Српској православној цркви. Срби су своју школу сместили у приземну кућицу, после пожара. 
Светог Саву 14. јануара 1888. Та идеја прихваћена је од проте Јована и одбора с радошћу. Како је текла припрема за реализацију немамо одређене информације.

Прихваћена учитељева идеја спроведена је у дело на Дан Светог Саве, 14. јануара 1888. То је била прва Светосавска прослава и уопште прва забава виђена у Мркоњић Граду. До тога дана у граду није било никакве забаве. Прослава је приређена „тако сјајно и са успјехом, да је задивила многобројну публику, која је забаву посјетила, колико ради забаве, толико из радозналости.“3 Одржана је у просторијама комуналне (државне)

Српска школа као институција сметала је окупаторској аустроугарској власти. Настојала је да уништи српске школе, али и да прогони Србе. Посебно се у томе истицао Куглер, управник среске испоставе у Мркоњић Граду. Вршећи тиранију над српским народом он је сменио и општинског начелника Србина Тоду Гашића, а поставио римокатолика Стипу Шкарицу. Да би се захвалио за услугу Шкарица је без знања Срба за Куглера израдио Диплому почасног грађанина. На свечаност су позвани и српски свештеници. Тада је свештеник и учитељ српске школе Стево Чулић одржао здравицу у којој је навео све Куглерове неправде које је учинио и чини Србима, тако да после тога он диплому није ни примио. Сутрадан је, под изговором да је зграда несигурна, послао жандаре и истерао српске ученике, учитеља Стеву Чулића и запечатио српску школу. Прота Јован je, у знак протеста, затворио цркву и однео Куглеру кључеве речима: „Затворили сте нам школу. Ево Вам и кључеви од цркве. Црква и школа нам је једно и ми не идемо у цркву док нам је школа затворена.“ Тим поводом јајачки предстојник (поглавар) Фаркаш рекао је проти Јовану: „Шта се тебе тиче попе школа и народ. Твоје је само служити цркву“ и на то је добио одговор: „Господине престојниче! Ја сам народ и народ је ја. И када ми извадите језик онда ћу престати за свој народ говорити.“ За протојереја (проту) произвео га је 20. августа 1883. Сава Косановић, митрополит дабробосански. Са својим сином Миланом, младим правником, много је заслужан да је митрополит Ђорђе Николајевић завештао новац за српску школу у Мркоњићу која је, и поред спутавања од стране власти, завршена 1894. Око градње цркве и школе прота Јован био је најактивнији, радио је, трудио се и поднео бриге и муке највише, а жртвовао је и личне приходе. Аустроугарске власти над протом Јованом појачале су надзор од 1892. зато што је његов син Милан побегао у Србију. И поред тога, он није променио своје држање. Један је од покретача и организатора српског народног покрета за црквено школску аутономију 1896. и члан делегација у Сарајеву 1899. и Пешти 1900. Био је члан епархијског црквеног суда. За српску школу у Мркоњићу поклонио је 1909. године 1000 круна као прилог, а следеће године 10. августа завештао је цркви своју кућу у вредности 2000 круна као вечни спомен. Умро је 31. октобра 1911. у Мркоњић Граду, опојан и испраћен од 8 свештеника и многобројног народа. Од њега, говором у цркви у име народа Мркоњићке општине, опростио се свештеник Стојан С. Тркуљић, на раскршћу пред Хотел Босном свештеник Павле Убавић, а над гробом одборник Перо Граић. Имао је три кћери Стану, Мару, Милеву и синове Милана, Душана и Вукосава, од којих су га надживели једна кђер и један син.

3 Стојан Тркуљић, Српско-православна основна школа у Вариару - Мркоњић Граду, „Нови источник“, (VI, 1939, бр. 11 (новембар), 349-352; VII, 1940, бр. 6 - 7 (јун - јул), 198-205; бр. 9 - 10 (септембар - октобар), 274-281. Наведени цитат је у бр. $6-7$ (јун - јул), 201. Иначе овај рад, по казивању аутора С. Тркуљића, настао је тако што га је 
школе зато што другог, погодног места за одржавање забаве није било. Beћ у 6 сати увече народ је почео да долази „у школску дворану и до 7 сати била је пуна, тако, да многи нијесу имали мјеста, да сједе. Штета је, што није више простора било, те се је тако више фамилија задржало код куће, а неке су се повратиле испред школске дворане кући, да уступе мјесто страним гостима. ${ }^{64}$ Извођачи ове прве Светосавске прославе били су учитељ, ђаци и омладина. Програм, који није изведен по редоследу наведеном у позивници, почео је у 19:30 часова и састојао се из три дела:

Поздравни говор учитеља Стојана Тркуљића је био на почетку првог дела програма. Нажалост, он није забележен и сачуван, као ни позивница за скуп или ми до ње нисмо дошли.

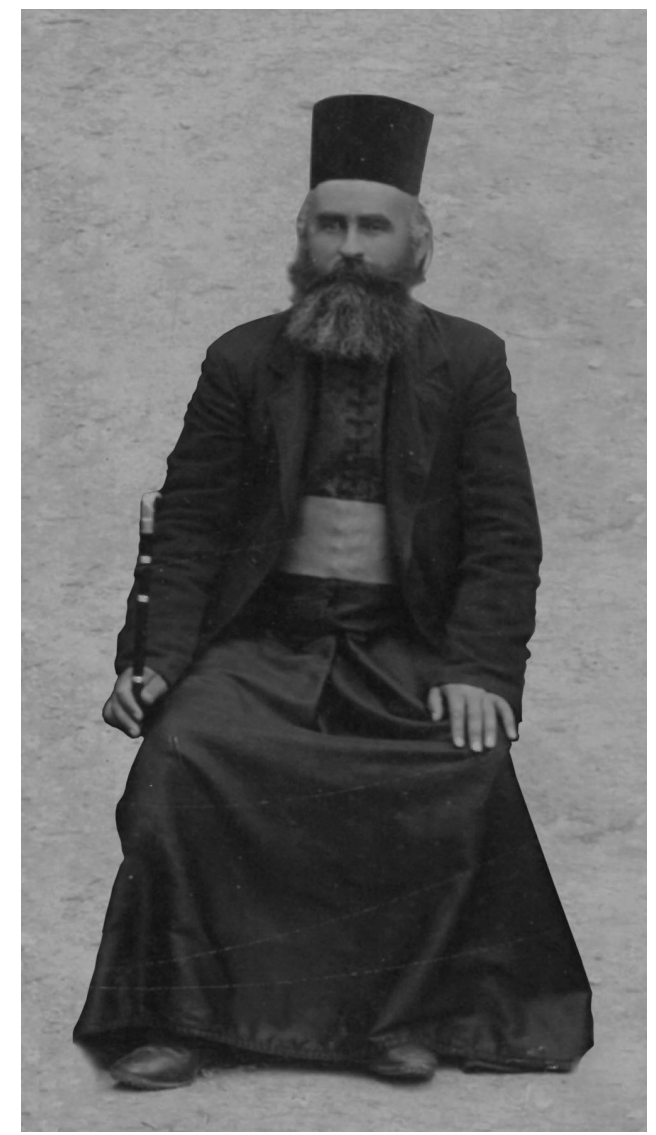

Учитељ и свештеник Стојан С. Тркуљић

Затим је под диригентским вођством Ђуре Диклића, учитеља комуналне школе, основане претходне 1887. године, мушки хор, састављен

„побиљежио по архивским подацима, своме запамћењу и испитивању старих људи.“

4 Босанска вила, III, 1888, бр. 5 (1. III), 78. 
само од Срба, отпевао у 4 гласа песму У ливади под јавором вода извире. Није нам познато која је варијанта песме код извођења певана. Да ли су у питању прво забележени стихови или они познати данашњој публици. Зато овде доносимо данашњу, познату варијанту песме, а и оне које су прво забележене. ${ }^{5}$

У ливади под јасеном

Вода извире, вода извире:

У ливади под јасеном

Хај, вода извире.

Ту се шета лепа Ката,

Воду захвата, воду захвата.

Ту се шета лепа Ката,

Хај, воду захвата.

Момче јој се с брега баца

Златном јабуком, златном јабуком.

Момче јој се с брега баца

Хај, златном јабуком.

Узми Като, узми злато,

Моја ћеш бити, моја ћеш бити.

Узми Като, узми злато,

Хај, моја ћеш бити.

5 Аутор С. Тркуљић дао је у раду назив песме како смо га навели и рекао да је она спремана из Бисернице, збирке попевки за четири мушка гласа (хорске песме), а њен изворни назив је: Bisernica, sbirka popievaka za četiri mužka grla. Sabrao ju i izdao „Vienac“ glasbeno-pjevačko družtvo u nadbiskupskom sjemeništu. Zagreb 1886. Knjigotiskara i litografija C. Albrechta.

Међутим, наслов који је С. Тркуљић навео је први стих песме Залог праве љубави јест перстен. Вук Стефановић Караџић објавио је у збирци песама „Мала простонародна славено-сербска песнарица“ у Бечу 1814. године под бр. 89. Потом и у збирци „Народне српске пјесме“, под бр. 311, штампаној у Лајпцигу 1824, па поново у збирци „Српске народне пјесме“, овог пута, под насловом Прстен је залог праве љубави и бр. 584, објављеној у Бечу 1841. Данас, на радију постоје две различите народне мелодије код ове песме. На ове податке указао нам је господин Ђорђе Перић, врстан познавалац ове проблеметике, којем захваљујемо и овим путем.

У примерку Бисернице (Библиотека Матице српске) коју смо имали нема песме под називом наведеним од аутора С. Тркуљића, а ни под онима које је објавио В. Караџић. Док се у објављиваним савременим текстовима песме, уместо под јавором, увек наводи под јасеном. 
Нећу, нећу, младо момче,

Имам драгога, имам драгога.

Нећу, нећу, младо момче,

Хај, имам драгога.

Прстен је залог праве љубави

У ливади под јавором вода извире,

Ту долази млада мома, воду завата,

Београду под зидове воду доноси,

Мирко јој се с града баца златном јабуком:

„Узми, мома, ту јабуку, моја ћеш бити.“

Мома ју је узимала, пак натраг баца:

„Нит” ћу тебе, ни јабуке, окани ме се.“

У ливади под јавором вода извире,

Ту долази млада мома, воду завата,

Београду под зидове воду доноси,

Мирко јој се с града баца златним ћерданом:

„Узми, мома, овај ђердан, моја ћеш бити.“

Мома ђердан узимала, пак натраг баца:

„Нит’ ћу тебе, ни ђердана, окани ме се.“

У ливади под јавором вода извире,

Ту долази млада мома, воду завата,

Београду под зидове воду доноси,

Мирко јој се с града баца златним прстеном:

„Узми, мома, овај прстен, моја ћеш бити.“

Мома прстен узимала, на прст натаче:

„Оћу тебе, и твој прстен, и ја сам твоја.“6

Иза тога је ученик 4. разреда српске школе Шпиро Касабашић ${ }^{7}$ рецитовао песму Дижсимо школе! Јована Јовановића Змаја, а која гласи:

6 Сабрана дела Вука Караџића, књига четврта, Српске народне пјесме, књига прва, 1841, Београд 1975, 378.

7 Он је пред Други светски рат био у Книну магационер Шипадовог предузећа. Син је Јована Касабашића, учитеља српске школе у Мркоњић Граду до окупације Босне и Херцеговине. Тада га је аустроугарска власт казнила и забранила му да буде учитељ. Од тога времена до смрти био је писар код проте Јована Пећанца и појац у цркви. (С. Тркуљић, Српско-православна основна школа у Вариару - Мркоњић Граду, Нови источник, (VI, 1939, бр. 11 (новембар), 350-351). 
Дижите школе,

Деца вас моле!

Јер има л' гора срама и стида,

Нег' своме чеду не дати вида!

Јер ево светлост свету се спрема,

А ваш да пород очију нема!

Дижите школе,

Деца вас моле!

Посејте њиву будућих дана,

Радите на њој са свију страна.

Не жал'те труда - сећајте с' плода,

Ил' нисте синци српскога рода!

Рани нам треба брзога лека, -

Отвор'те извор сретнија века!

Дижите школе,

Деца вас моле!

Јер брза река поред нас тече,

А ми на брегу наше несреће;

Ко има свести, отуд се клони, Окати виде, брег нам се рони.

Градимо брода нема се часа,

Сутра смо жртва бурних таласа.

Дижите школе,

Деца вас моле!

Ил' нека зине то наше гробље,

А народ наш ће остати робље,

Слепо ће поћи у тај свет бели

И молит' мрве да му удели,

А кад се нашег немара сети,

Само ће знати неоце клети.

Дижите школе,

Деца вас моле!

„Скини ми, бабо, с чела облаке,

Не дај ме, бабо, у просијаке!

Не штеди, бабо, рад добра мога,

Смилуј се, бабо, тако ти бога!

Јер биће дана, ал' неће среће, 
И биће људи, ал’ Срба не ће!

Помози, бабо, помоћ' ћу и ја, Да српско име јоште просија!

Дижите школе, Деца вас моле! ${ }^{8}$

После ове Змајеве песме поново је мушки хор отпевао песму: Пушку на клин, мач у ток, сад је браћо други скок. У поменутој Бисерници забележена је нотним записом и текстом на овај начин:

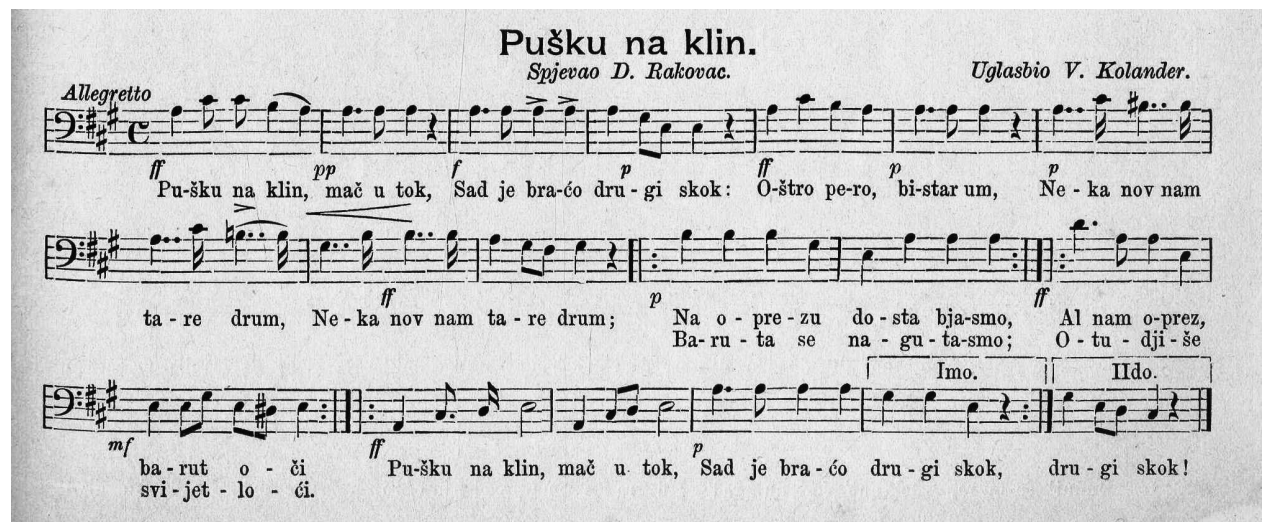

На крају првог дела Перо Граић, ${ }^{9}$ ученик 4. разреда српске школе рецитовао је баладу Мите Поповића Српска мајка са стиховима:

8 Певанија Змај-Јована Јовановића, Одабране целокупне умотворине у песми и прози са опширним животописом Змај песниковим. Српске књижаре Браће М. Поповића код „Светог Саве“, у Н[овом] Саду 1882, 88-89.

9 Граић Николе Перо рођен је 29. јуна/12. јула 1875. у Мркоњић Граду, а у истом месту умро је 31. марта 1965. Завршио је основну школу и потом се бавио трговином. Иако световњак био је редовни члан ужег Епархијског савјета и ширег епархијског Управног и просвјетног савјета. Активно је учествовао у борби Срба за црквеношколску аутономију. Од аустроугарских власти означен је као српски радикал (Serbisch-radikal gesinnt). Почетком рата 1914. је ухапшен и као таоц одведен у затвор у Јајце, па као велеиздајник спроведен у окружни затвор у Травнику. Из њега је 30. јануара 1915. одведен у окружни затвор у Сарајево у којем је био под истрагом. Иако је као велеиздајник био у наведеним затворима није суђен као велеиздајник. Политички је припадао Народној радикалној странци. За члана Банског већа Врбаске бановине за Срез мркоњићградски постављен је 3. VII 1930. Био је председник Мркоњићке општине, као и председник Управног одбора Прометне банке д. д. у Мркоњић Граду 1931 - 1932. Први пут биран је за народног посланика 1931. Био је 1933. члан оснивачког одбора Удружења трговаца за Срез мркоњићградски, а касније и председник тога удружења. На почетку рата 1941. избегао је усташки покољ и сво време рата живео је у Младеновцу код ћерке Олге, удате Мирковић. На крају, напоменимо и то да је Перо Граић деда познатог композитора Радослава Граића. 
Остарела мајка Два имала сина, Два јутарња зрака Два зелена крина.

Огрејано сунце Баш далеко иде, Ал лепших синова Тешко још да виде.

Што је роса дробна Лисју или трави, Што је мирис цвету, Што ј' око у глави:-

Што j' слобода сужном Кад у гвожђу цвили;

Толико су мајци

Синови јој били.

Што је небу сунце, Што је ваздух тици, Што је бурма златна Верној милосници;

Што су гусле слепцу, Што су вили крилаТолико је мајка Синовима била!

Ал насташе бурни И одсудни дани, Зазвекташе звечни Челик-јатагани.

Напуни се ваздух Јуначкога крика, И задрхта земља Од топовског рика.
Заблисташе мачи Захорише горе, Заустави струје Валовито море.

И диже се клетва По целом Балкану: „Изрод, ко не тргне Сабљу оковану!

Изрод, ко не дође С нама на бојиште, Кад слобода српска, Кад народност иште!“‘

Кад су чули синци Да се дигла раја, Одоше од мајке Без једног уздаја.

„Благосови, мајко!“ Тако су јој рекли, Кад су оружани Пред старицом клекли:

„Ако ти се, мајко, Не вратимо више, Из читуље живих Име нам се збрише:

Кани се лелека И кукања кани: Неумире никад Ко слободу брани!“

Нити да се вајка, Нит' речи изусти, Већ синке си мајка Благосовом пусти. 
И одоше синци

За слободу своју,-

Ал обоје паше

У крвавом боју.

Чекала их мајка

Да се кући врате

Кад сунчани зраци

Далек исток злате.

И кад се сунашце

Другом крају спрема-

Ал заман чекања:

Синова јој нема.

Недеља је била

Након митров-дана,

Ал ето ти једног

Црнорепа вра̂на.

На гранчицу суву

Спустио се лако,

Па са суве гране

Заграктао 'вако:

„Ево са бојишта

Жалосна весника:

Остарела мајко

Тешко ли тебека!

Синови ти красни

На разбоју паше,

За слободу златну

Крв и живот даше.
Првога ти сина -

Гракће тица с гране -

Баш у срце живо

Згодило је тане.

Твог другога сина -

Јаој што га роди!

Олово проклето

Баш у чело згоди!

Да ти незнам бо́ле

Би тешио ја те:

Синци ти се неће

Већ више да врате!“”

Завришта за браћом

Милостива села,

Заплакала горко

И родбина цела.

Ал беседи мајка:

„Што јадикујете?

Ил њихове сени

Што вређате свете?

Та моји су синци

Давно небу хтели:

Соколи су били,

Па су одлетели!“”

С ок о. ${ }^{10}$

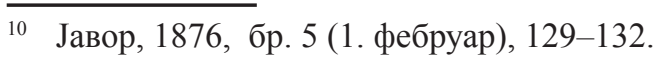


Други део забаве била је позоришна представа. Изведена је шаљива игра у једном чину Косте Трифковића под називом Пола вина, пола воде. Актери ове позоришне игре били су глумци дилетанти: Ристо Крецо, Ђорђо Качавенда и госпођице Јованка Игњатић и Сока Јоксимовић. Они ,су збиља зачудили публику својом вјештином. Публика је особито била изненађена вјештином и одважношћу двију младих Српкиња, којима се свак морао зачудити, нарочито, кад се узме у обзир, да им је ово први пут било, да су на бину изашле. За вријеме трајања цијеле забаве, владала је највећа пажња и ред. "“11 Иначе, једночинка Пола вина, пола воде премијерно је изведена 30. маја 1875. у Народном позоришту у Београду и до 1914, по подацима, репризирана је 14 пута.

Трећи део су испуниле томбола и игранка са српским колима.

Том приликом „чиста прихода од забаве било је: 110 форинти. Овим је црквена општина подмирила своје дуговање и могла да ми исплати заостале учитељске плате.“12

Поред наведеног прихода на првој Светосавској забави у Мркоњић Граду познати су нам и добровољни прилагачи (дародавци) с износом новца. Они су из више места у Босни, а позната су и забележена њихова имена која овде наводимо. То су: Ристо Ђ. Бесаровић и Васо Краљевић по 10, а митрополит Ђорђе Николајевић и Глигорије М. Јефтановић по две форинте, сви из Сарајева; Васо Кукољ из Кнежева (Скендер Вакуфа) шест форинти; Саво Сурутка пет, Миле Јанковић и Митар Дабовић по две форинте из Бања Луке; свештеник Стеван Ш. Бубњевић из Герзова и управитељ испоставе у Бугојну Мосаковски по три форинте; срески поглавар Барчај две и по и Мухарем ага Сарач две форинте из Јајца; Мића Црногорчевић две, Јово Мандић и Вујо Виревић по једну форинту из Бихаћа (Бишћа); свештеник Миле Попадић и Јово Ћебеџић из Кључа, Васо Видовић и Ђорђе Боснић из Босанске Градишке, столар Петар Бајт из Бочца и рудар Сладечек из Мајдана по једну форинту; начелник Шпиро Шкорица (Стипе Шкарица), браћа Срђеновићи, браћа Бесаре по две, а Перо Срђеновић, Манојло Крецо, Тоде Пашић (Гашић), поштар Раш, вођа (фирер) Илија Зобеница, жандари Тодор Тошић и Јово Босрок, Антон Преглер, Никола Граић по једну форинту, док је Илија Арежина дао 80 и Илија Молновић (Малиновић) 40 новчића, сви из Мркоњић Града. ${ }^{13}$

Приређена приредба имала је велики одзив и успех код публике, упркос томе што је била прва забава у граду и што је један део публике дошао само из радозналости. У прилог томе говоре и дати добровољни прилози. Поред Срба, гостију са стране, а у првом реду из Јајца и 11 Босанска вила, III, 1888, бр. 5 (1. III), 78.

12 С. Тркуљић, Нав. дело, VII, 1940, бр. 6 - 7 (јун - јул), 202.

13 Босанска вила, III, 1888, бр. 7 (1. IV), 111. 
Герзова, на приредби ,је било доста браће римокатолика са фамилијама, а и лијеп број наше браће мухамеданаца. Тако је ова прва светосавска бесједа у овоме мјесту не само достојанствена прослава српског просветитеља, него уједно и вјесник братске слоге, љубави и сједињења међу растројеном браћом. "14 Какав је утисак Светосавска прослава оставила на публику најбоље говори чињеница да је после званичног програма „играло се пјевало и веселило баш онако по српски. Свак је био задовољан, тако, да се весело коло није растргло до 9 сати у јутру.“15 Прва Светосавска прослава у Мркоњић Граду, уз наведену материјалну корист, имала је значајан утицај и на очувању националне свести, православља и политичког јединства. Уз учешће свих Срба одржавана је сваке године док је окупација трајала, све до 1914. Ова прослава за последицу је имала и то да је учитељ Ђуро Диклић, Србин из Оточца, због сарадње са српским учитељем и српском школом, премештен и напустио је град „по највећој зими“. После њега дошао је за учитеља комуналне школе Хрват, Иван Кларић и забранио је да се у државној школи одржава прослава Светог Саве. Светосавска беседа и прослава од 1894/95. школске године одржаване су редовно у згради нове саграђене српске православне основне школе, задужбини дабробосанског митрополита Ђорђа Николајевића, у великој просторији која је служила само за ту намену и за учионицу, а њен спољни изглед је ово:

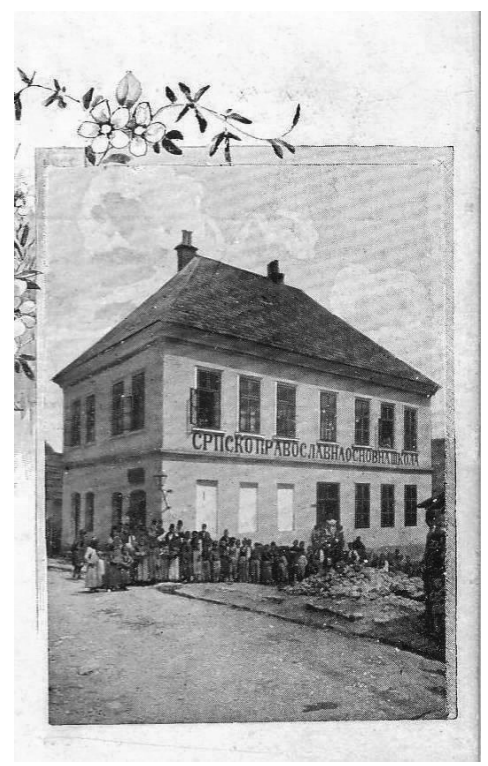

Из архиве Културно информативно образовног центра „, Петар Кочић“ Мркоњић Град

14 Босанска вила, III, 1888, бр. 5 (1. III), 78.

15 Исто. 
Овакво приређивање и одржавање Светосавске прославе свакако је допринело да се размишља и о стварању једног певачког друштва. Нешто више од једне деценије потом оно је и основано 9. фебруара 1900. у Мркоњић Граду. Опет на предлог и заузимање Стојана Тркуљића с учитељем Богољубом Глишићем, учитељицом Анђелијом Бугарски и Српском православном црквеном општином на челу с протом Јованом Пећанцем. Назив је добило у знак захвалности и сећања на добротвора српске школе и народа, дабробосанског митрополита Ђорђа Николајевића. Друштво је радило под именом Српско православно црквено пјевачко друштво „Николајевић“ и по правилима донетим у години оснивања која су касније допуњавана. Своју делатност започело је у јеку борбе српског народа у Босни и Херцеговини за црквено школску аутономију под окупацијом Аустроугарске. У тим условима, поред основног музичког рада, припремања и одржавања концерата духовне и световне садржине, приредби, села и забава, имало је и шири друштвени, културни, просветни и национални значај у српском народу. Упоредо с тим оно је оформило и своју библиотеку. Увећавало је њен књижни фонда, да би и на тај начин допринело уздизању и очувању националне свести и просвећивању српског народа. До почетка Првог светског рата оно је било смештено у згради српске основне школе. Све оно што је имало до рата „од архиве, намјештаја, књига, и сва гардероба друштва ,Николајевић’, све је разнешено, испретурано и већим дијелом уништено, пошто је пол[ицијска] власт тражећи разне списе, слике и књиге, отворила и оставила отворене школске и друштвене ормаре, столове и књижницу. ${ }^{616}$ После рата поседовало је зграду коју је с времена на време оправљало и штитило од пропадања, а називана је Дом певачког друштва „Николајевић“. То је био центар готово свих догађања и културних дешавања између два светска рата. Своју племениту културну, а можемо рећи и просветну делатност Српско православно ирквено пјевачко друштво „Николајевић“ вршило је све до Другог светског рата.

Миле Ј. Станић Архив САНУ

Кључне речи: Свети Сава, прослава, беседа, Мркоњић Град, учитељ Стојан С. Тркуљућ, прота Јован Пећанац.

16 С. Тркуљић, Нав. дело, VII, 1940, бр. 9 - 10 (септембар - октобар), 280. 
Mile J. Stanić

\section{THE FIRST ST SAVA'S DAY CELEBRATION IN MRKONJIĆ GRAD IN THE YEAR 1888}

The article "First St Sava's Day Celebration in Mrkonjić Grad in the Year 1888 " draws attention to the 1888 ceremony held on St Sava's Day, the first public entertainment ever held in Mrkonjić Grad, a town in today's Republic of Srpska. The article names the participants in the event and describes the programme of the performance, states the collected proceeds and lists the names of the voluntary contributors. In addition, the article points to the audience's attendance, emphasising the significance and impact of the said celebration. In a little over a decade, the regular staging of St Sava's Day Celebration led to the foundation of a choral association known as The Nikolajević Serbian Orthodox Ecclesial Singing Company. 